\title{
A condolence letter to support bereaved parents after a child's death
}

\author{
Carta de condolencias para apoyar a los padres en duelo después de la muerte de un hijo \\ Hüseyin Çaksen* \\ Department of Pediatrics, Division of Behavioral-Developmental Pediatrics, Necmettin Erbakan University, Meram Medical Faculty, Meram, Konya, \\ Turkey
}

Dear Editor,

A child's death is a traumatic experience that can put parents at risk for adverse mental and physical health during bereavement. Health professionals can benefit from knowing these risks to best support bereaved parents. ${ }^{1}$. Here, we present some considerations for health professionals to support bereaved parents who are grieving a child's death.

Spirituality is a vital dimension of a child's experience at the end of life: providing comfort, support, and a sense of connection. Spiritual care is paramount to address the substantial spiritual distress that may develop ${ }^{2}$. All professionals involved with child deaths should ensure that procedures are in place to support parents, to allow them to say goodbye to their child, to be able to understand why their child died, and to offer the parents follow-up appointments with appropriate healthcare professionals ${ }^{3}$. Kenny et al. ${ }^{4}$ noted that the most repeated finding across the 11 papers was the treating hospital's integral role for the bereaved parents. The treating hospital is central in providing support to parents through their child's end-of-life journey and subsequent bereavement ${ }^{4}$. Nursi ${ }^{5}$ described the following condolence letter to support spiritually bereaved parents after a child's death:

"If the world had been eternal, and man was to have remained in it eternally, and separation had been unending; grievous sorrow and despairing woe would have had some meaning. But, since this world is a guesthouse, wherever the dead child has gone, you, and we too, shall go there. Moreover, he is not the only one to die; it is a general highway. And, since separation is not forever, you will meet with him in the future, both in the Intermediate Realm and the hereafter. One should say: "The command is God's. He gave him, and He took him away," and: "All praise be to God for all circumstances," and offer thanks in patience ${ }^{5 "}$.

"We use the mentioned condolence message in bereaved parents, who lost their children, and we observe great psychosocial relief in many bereaved parents.

In conclusion, we believe that it is important for health professionals to recognize ethnic aspects of spirituality and implement care measures that support families' spirituality with a dead child. We also think that all bereaved parents following a child's death should be supported spiritually.

\section{Correspondence:}

${ }^{*}$ Hüseyin Çaksen

E-mail: huseyincaksen@ hotmail.com 1665-1146/@ 2020 Hospital Infantil de México Federico Gómez. Published by Permanyer. This is an open access article under the CC BY-NC-ND license (http://creativecommons.org/licenses/by-nc-nd/4.0/).

Available online: $24-02-2021$ Bol Med Hosp Infant Mex. 2021;78(1):85-86 www.bmhim.com 


\section{Conflicts of interest}

The author declares no conflict of interest.

\section{Funding}

None.

\section{References}

1. October T, Dryden-Palmer K, Copnell B, Meert KL. Caring for parents after the death of a child. Pediatr Crit Care Med. 2018;19:S61-8.
2. Petersen CL. Spiritual care of the child with cancer at the end of life: a concept analysis. J Adv Nurs. 2014;70:1243-53.

3. Garstang J, Griffiths F, Sidebotham P. What do bereaved parents want from professionals after the sudden death of their child: a systematic review of the literature. BMC Pediatr. 2014;14:269.

4. Kenny M, Darcy-Bewick S, Martin A, Eustace-Cook J, Hilliard C, Clinton F, et al. You are at rock bottom: a qualitative systematic review of the needs of bereaved parents as they journey through the death of their child to cancer. J Psychosoc Oncol. 2020;38:761-81.

5. Nursi BS. The seventeenth letter. The addendum to the twenty-fifth flash. A letter of condolence on the death of a child. In: The Letters. The Collection of Risale-i Nur; 2012. Available from: http://www.erisale.com/index.jsp?locale=en\#content.en.202.99. Accessed 10 Nov 2020 